\title{
Detection of Bioactive Compounds in the Mucus Nets of Dendropoma maxima, Sowerby 1825 (Prosobranch Gastropod Vermetidae, Mollusca)
}

\author{
Anne Klöppel, ${ }^{1}$ Franz Brümmer, ${ }^{1}$ Denise Schwabe, ${ }^{2}$ and Gertrud Morlock ${ }^{3}$ \\ ${ }^{1}$ Department of Zoology, Biological Institute, University of Stuttgart, Pfaffenwaldring 57, 70569 Stuttgart, Germany \\ ${ }^{2}$ Animal Evolutionary Ecology, Zoological Institute, University of Tübingen, Auf der Morgenstelle 28, 72076 Tübingen, Germany \\ ${ }^{3}$ Institute of Food Chemistry, University of Hohenheim, Garbenstraße 28, 70599 Stuttgart, Germany
}

Correspondence should be addressed to Anne Klöppel; anne.kloeppel@bio.uni-stuttgart.de

Received 31 March 2013; Accepted 24 May 2013

Academic Editor: Horst Felbeck

Copyright (C) 2013 Anne Klöppel et al. This is an open access article distributed under the Creative Commons Attribution License, which permits unrestricted use, distribution, and reproduction in any medium, provided the original work is properly cited.

\begin{abstract}
The sessile suspension-feeding wormsnail Dendropoma maxima, Sowerby 1825 (Vermetidae) secretes a mucus net to capture planktonic prey. The nets are spread out over the corals and often have remarkable deleterious effects on them like changes in growth form and pigmentation shifts not uncommonly resulting in tissue necrosis. Until now, there is no explanation for this phenomenon although the indication as well as theories about its genesis is mentioned in several publications. Vermetids are well studied concerning the intraspecific competition with neighboring individuals but not in their interaction with other taxa like corals or fish. We did extensive in situ video recording and observed that fish avoided the plankton-load nets although several specialized taxa are known to be molluscivores, mucivores, and/or feed on plankton. As many molluscs use chemical weapons to combat feeding pressure and to defend themselves against predators, we screened empty and plankton-load mucus nets for potential bioactive metabolites. Bioactivity testing was performed with a recently developed system based on a chromatographic separation (high-performance thin-layer chromatography (HPTLC)) and a bioassay with luminescent bacteria Vibrio fischeri. Thus, we found at least two active compounds exclusively accumulated by the wormsnails themselves. This is the first record of bioactive properties in the whole family of Vermetidae.
\end{abstract}

\section{Introduction}

The vermetid gastropod Dendropoma maxima, Sowerby 1825 (Vermetidae, Littorinimorpha, Gastropoda) is a dominant, very abundant encrusting species of outer tropical reefs and widespread throughout the IndoPacific [1-3]. In the Red Sea, $D$. maxima populations can attain substantial densities, a phenomenon largely restricted to that area $[4,5]$. Wormsnails mainly live in the infralittoral and upper-circalittoral between the breaker zone and the outer reef edges facing the current $[1,2,6]$. To combat the competition for space and nutrients, wormsnails developed particularly strong substrate preferences. In the Red Sea, substrates are living corals like hydrozoan Millepora spp. (Figure 1(a)) and Porites spp., dead coral rock next to the reef edge, or they can be found on the nonliving reef flat substratum $[2,7]$.
Vermetids are a rather peculiar and poorly studied family. Although they are common inhabitants of coral reefs and rocky shores, little is known about the basic biology of most species [5]. Wormsnails have an irregularly uncoiled calcareous shell, cemented to or embedded in the substrate $[2,3,6,8]$. Growth rate of the shell is rather fast and enables the vermetid to escape overgrowth by corals and to maintain access to food [9]. Often, only the proteinaceous operculum is seen forming a plug to the accessible shell aperture whose diameter is a good index of body size $[5,10]$.

Aspects of the feeding ecology of vermetids have been examined in a number of studies (e.g., $[3,6,8,9,11]$ ). Wormsnails are active and passive suspension feeders [9]. Next to ctenidial cilia filter feeding, what is marginally in $D$. maxima, vermetids excrete a sticky mucus net (containing mucopolysaccharides and mucins (glycosylated proteins)) 


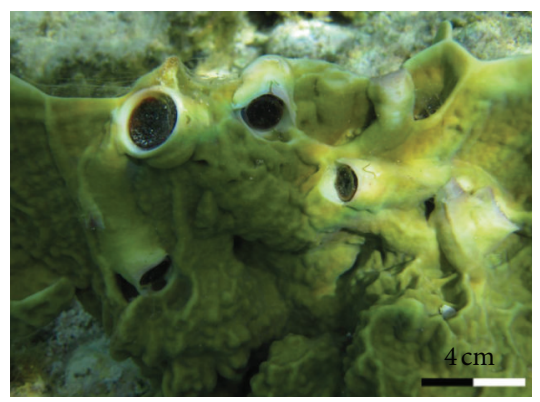

(a)

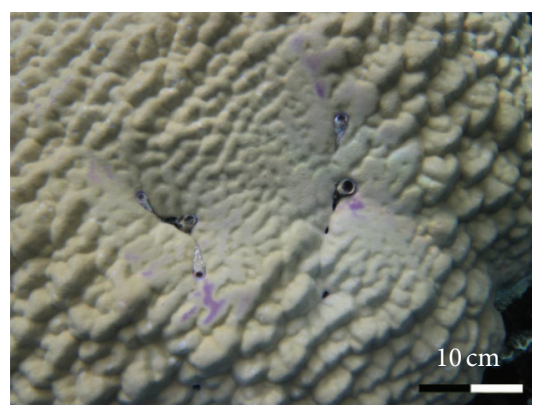

(b)

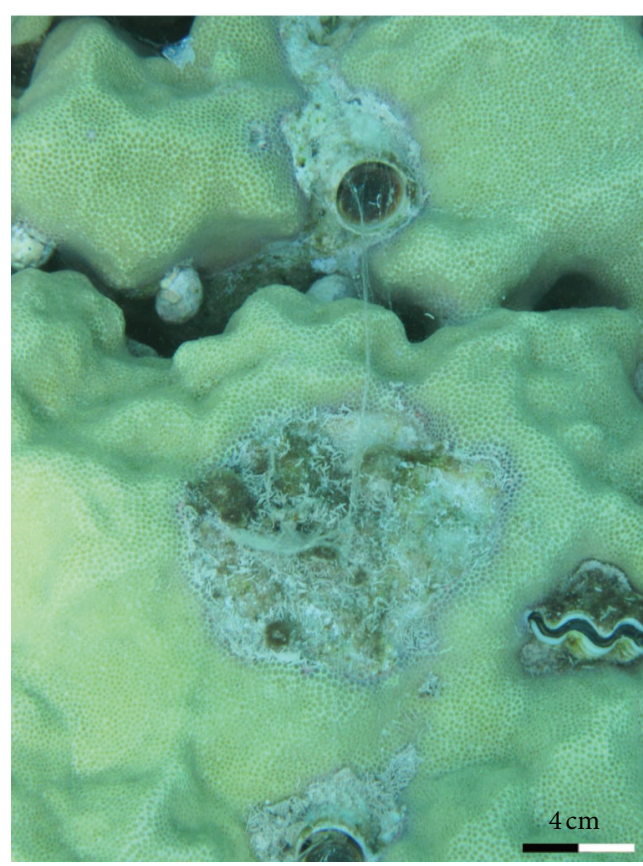

(c)

Figure 1: Deleterious effects of the vermetid gastropod Dendropoma maxima on associated corals. Several individuals growing inside the hydrozoan fire coral Millepora platyphylla that minimizes the contact area between coral tissue and nets because of its erected and branching growth form (a). Morphology and pigmentation shift of the massive coral Porites sp. where nets get in touch with the coral tissue. The naturally uneven surface exhibits a more even, flatted one (b). Dead coral tissue of a mucus net affected area (here: dimension approximately $20.1 \mathrm{~cm}^{2}$ ) of Porites sp. overgrown by algae (c). The highly particle-enriched veils are negatively buoyant and descend on the coral tissue underneath. Almost the whole contact surface between net and coral tissue is degenerated.

well adapted to capture near-bed small planktonic organisms consisting mainly of copepods, rhizopods, meiobenthos, and detritus $[3,6,8,11,12]$.

Analyzing the interspecific interaction between wormsnails and their living coral substratum disclosed that $D$. maxima depresses coral growth in the region of infestation (Colgan in [9]). Zvuloni et al. [1] reported that the presence of D. maxima in the Gulf of Aqaba (Red Sea) was associated with morphological anomalies and reduced size of corals they live inside. This suggests either that wormsnails harm corals or that they recruit preferentially to degraded coral habitats [13].

The extruded webs seem to be more detrimental on surrounding organisms than the vermetids' body. They often contact neighboring substrates including corals [2, 14]. Field experiments clearly demonstrated deleterious effects of vermetid nets on corals [13]. Since the underlying mechanisms are still unknown [13], theories speak of abrasive effects on the coral polyps, the competition for substrate and planktonic food, or the presence of bioactive secondary metabolites [1, 15]. Presumably, there is an additional effect of surrounding invertebrate colonies and associated fish. For example, the guard crab Trapezia serenei ameliorates the strong negative effect of $D$. maxima on pocilloporid coral growth rate by dislodging and consuming the vermetid mucus (as they do with sediments) [16].
Fishes are notable among vertebrates for having comparatively broad and flexible diets $[17,18]$. In the Red Sea, many mucoid (e.g., Labroides spp., Chaetodon spp.) and molluscivore (e.g., Anampses spp., Bodianus spp., Cheilinus spp.) reef fish are known. Until now there is no publication about any predator-besides the guard crab Trapezia serenei as suggested in [16] — that feeds on the wormsnail's mucus even nets are additionally loaded with plankton, mainly copepods, what should be of great interest for plankton feeding reef inhabitants. Already in 1973, it was assumed that vermetid mucus must be distasteful to other animals to function as an effective feeding inhibitor [19].

Molluscs are a dominant group within aquatic invertebrates producing bioactive substances. Among them, opisthobranchs, especially nudibranchs, are mostly preyed on [20]. As molluscs often lack sufficient morphological protective mechanisms, they have adopted an impressive array of defensive strategies [21, 22]. Passive and active chemical defensive (mucus) secretion is known in numerous marine molluscs $[23,24]$. Besides mechanical protection, gastropod mucus may contain specific products to render the animal poisonous, distasteful or irritating, or some combination of these known from many mucus producing invertebrates $[19,23,25]$. Experiments with carnivorous fishes as potential predators have indicated the possession of chemical defense mechanisms in opisthobranch gastropods, including 
the secretion of strongly acidic or noxious substances with ichthyotoxic and antibacterial properties [26-28]. Many of these deterrents are diet-derived or built up in vivo from dietary precursors (e.g., sponges for dorid nudibranchs) and not synthesized de novo [22, 29-31].

Until now, nothing is known either about predators feeding on the plankton-load nets or any interaction between ambient marine organisms (besides corals) and the mucus veils of Vermetidae. No studies have been done analyzing the toxic potential of mucus net ingredients on corals associated with vermetid gastropods, on surrounding reef inhabitants or their potential application in human medicine. Marine invertebrates are one of the most efficient sources for bioactive secondary metabolites with pharmaceutical properties $[24,32-35]$. Some have entered preclinical and clinical trials or even made it to the commercial sector [34, 36-38].

Therefore, we made video observations to document the interaction reef fish vermetids concerning the capability as food source and screened the nets for bioactive substances. A recently optimized system (high-performance thin-layer chromatography (HPTLC)/bioassay) for bioactivity screening in invertebrates was used [39].

\section{Material and Methods}

2.1. Study Area. Field work was carried out in the Gulf of Aqaba (Red Sea) along the Egyptian eastern and western coastline near Dahab (Suleiman Reef), $100 \mathrm{~km}$ north of Sharm El Sheikh and at Mangrove Bay (Sharm Fugani), $30 \mathrm{~km}$ south of El Quseir (Egypt) during the period from April 15 to December 15, 2010. Dendropoma maxima individuals are very common on the reef crest using corals (Millepora dichotoma, Millepora platyphylla (Figure 1(a)), Porites lutea, and Porites nodifera) as their main substrate, and on the rear reef flat, where organisms are often attached to blocks of dead or live coral rubble. The latter feature makes D. maxima very suited for aquaria experiments. Their habitat is always characterized by intense wave action, strong current, and high abundance of reef fish.

2.2. Documentation and Video Recording. Filming experiments were done in front of several wormsnail populations on the reef flat, edge, and slope, covering more than 12 hours at different day times. Filming was done with a digital camera in an underwater case (PowerShot G9, Canon, Germany). The camera was attached to a small flexible tripod and positioned near a wormsnail community. After focusing, the system was left alone for half an hour in order to not interfere with the organisms. The video material was evaluated by identifying the fish species $[40,41]$ and counting their net attacks or bites.

2.3. In Situ and Ex Situ Sampling of Mucus Nets. In situ sampling was focused on the shallow subtidal zone and done via snorkeling. All individuals exhibited an aperture width of about $15 \mathrm{~mm}$. Secreted mucus nets were collected with a metal wire ring positioned on the outside perimeter of the shell's aperture. Prior to collection, the planktonload net was wrested from the wormsnail by twisting the metal device. Removing the nets stimulated the wormsnails to start producing a new one within less than a minute. The combined veils were transferred to the laboratory and extracted immediately. Additionally, plankton was caught with a $15 \mu \mathrm{m}$ pore-sized plankton net and sediments were taken next to the wormsnails' in situ habitat.

Individuals, all of about $15 \mathrm{~mm}$ aperture width, used for ex situ net extraction were collected from horizontal surfaces at depths between 0.5 and $1.5 \mathrm{~m}$. Only animals attached to lose coral blocks were transferred to the aquaria without getting exposed to air and brought back after one day and final plankton feeding. Before inserting, the coral blocks were cleaned with a wire brush to get rid of attached microfauna and flora that could diffuse in the ambient water. The plankton-load net produced in situ was removed. The ex situ tank was flushed with filtered seawater at $25^{\circ} \mathrm{C}(<15 \mu \mathrm{m}$ pore size) to get rid of most of the suspended particles. Unfiltered seawater contained a high density of visible detrital particles; the filtered seawater appeared clear. The aquarium was equipped with a perforated acrylic glass rack on which coral blocks were positioned. This facilitates a controlled current flow from below and sidewise induced by pumps. The vermetids were triggered to produce the mucus nets floating upwards by this external stimulus. A ventilation-airstone positioned under the rack provided small air bubbles that attach to the translucent mucus strands rendering the nets visible [8]. The back side of the aquarium was covered with a black plate to enhance the contrast. Collection was done according to in situ sampling. Clear nets from different individuals were combined and covered with solvent.

2.4. Extraction of Mucus Nets. Mucus nets (collected in situ and ex situ) from different individuals were combined in reaction tubes and extracted exhaustively over night in methanol, ethanol, diethyl ether, or ethyl acetate ( 5 veils $\mathrm{mL}^{-1}$ solvent). After centrifugation, the supernatant was transferred in HPTLC prevalent vials. Sediment and plankton samples were weighed and extracted according to the mucus webs ( $\sim 500 \mathrm{mg} \mathrm{mL}^{-1}$ solvent).

\subsection{High-Performance Thin-Layer Chromatography} (HPTLC). Chromatography was performed on silica gel $60 \mathrm{~F}_{254}$ plates (Merck, Darmstadt, Germany). All plates were prewashed by development with methanol, then dried at $100^{\circ} \mathrm{C}$ for $15 \mathrm{~min}$, and stored protected in a desiccator. Samples were applied on the plate as $4 \mathrm{~mm}$ bands, $9 \mathrm{~mm}$ apart, $10 \mathrm{~mm}$ from the lower edge, and $15 \mathrm{~mm}$ from the left edge by means of the Automatic TLC Sampler 4 (ATS4, CAMAG, Switzerland). The application volume of the mucus extracts ranged from 20 to $80 \mu \mathrm{L}$ perband. Plates were developed with a twelve-step gradient by use of the Automated Multiple Development System (AMD2, CAMAG). The gradient was based on methanol, isopropyl acetate, and $n$-hexane (all technical grade and distilled before, BASF, Ludwigshafen, Germany) using $4 \mathrm{~mm}$ increments for the successively ascending migration distances. The drying time of the last AMD2 step was increased to be $15 \mathrm{~min}$ to avoid residual solvent interferences with the subsequent bioassay. Plates were documented by use of the 
DigiStore 2 Documentation System (CAMAG) at $254 \mathrm{~nm}$, $366 \mathrm{~nm}$, and with white light illumination (reflectance and transmission mode). Data processing for all instrumentation was performed with the software platform winCATS (CAMAG). Digital evaluation (transfer from image into analogue curve) was processed with separate software (VideoScan, CAMAG). The VideoScan settings used were: "track borders and slopes" was selected as integration mode, the Savitsky-Golay filter width was 11, and the offset was set to "yes." The track borders were set outside the fraction to enable background subtraction of the mean area of both borderline pixels.

2.6. Bioluminescence Assay with Vibrio fischeri. The developed plate was automatically immersed at a speed of $3.5 \mathrm{~cm} \mathrm{~s}^{-1}$ and with an immersion time of $1 \mathrm{~s}$, by means of the TLC Chromatogram Immersion Device III (CAMAG), into the luminescent bacteria (Vibrio fischeri) suspension, which was prepared according to the Bioluminex assay protocol (culture medium and buffer from ChromaDex, Boulder, CO, USA). For imaging, the HPTLC plate was placed in the compartment of the BioLuminizer (CAMAG), a dark chamber with a cooled 16-bit high-resolution CCD camera on top, specially designed for HPTLC-bioluminescence detection. In the compartment, the HPTLC plate was covered by a glass plate keeping the bacteria moist for a prolonged time. Images were captured with an exposure time of $30 \mathrm{~s}$ over a period of $30 \mathrm{~min}$. This allowed the study any time-dependent changes.

\section{Results}

3.1. Observations on Coral-Wormsnail Interaction. Observations made at Sharm Fugani (Mangrove Bay, South Sinai, Western Coast, Red Sea) and Suleiman Reef (Dahab, South Sinai, Eastern Coast, Red Sea) showed clear structural deformations of surrounding coral tissue inhabiting Dendropoma maxima. Less affected were fire corals of the genus Millepora (Figure 1(a)), due to the erected and branching growth form and the limited contact area between coral tissue and mucus webs. Most affected were massive corals of the genus Porites. This vermetid-coral association was always characterized by the wormsnail's mucus net covering parts of the coral block. Veils of different individuals often merge together forming huge sheets spread on the reef's surface. Some veils were so thick and dense that they trap gas bubbles, which get in touch with coral surface. Different states of host-coral degeneration were observable, beginning with pigment modification and surface structure flattening (Figure 1(b)) until the exposure of dead coral rock was overgrown by algae (Figure 1(c)).

3.2. Video Observation on Fish-Wormsnail Interaction. The evaluation of the video material does not show any fish biting or interested in the nets, despite the full load of plankton and bacteria accumulated within the web; even though amongst the identified reef fish were well known mucoid and plankton feeding organisms known to consume, for example, nutritious coral mucus aggregates. Observed reef fish sharing wormsnail habitats are listed in Table 1.
3.3. Sampling of Mucus Nets and Screening for Bioactive Metabolites (In Situ and Ex Situ). Preliminary tests preferentially showed unpolar and less polar components accumulated inside the nets. Therefore, ethyl acetate was chosen as extracting agent. Dipping in a Vibrio fischeri suspension leads to an inverse correlation between the concentration of bioactivity-reducing substances and the bioluminescence of bacteria.

Mucus nets with plankton sampled in situ and extracted with ethyl acetate showed at least four $V$. fischeri toxic substances (M1, M3-M5) detected by bioluminescence inhibition (black spots on luminescent background). Additionally, there was one metabolite (M2) enhancing the bioluminescence indicated by a white spot on the HPTLC plate (Figure 2(a)). Because of different application volumes, the more concentrated extracts led to a stronger decrease of luminescence on the plate. When nets are particle enriched (in situ), it is not possible to say whether the wormsnail or the captured plankton is responsible for product synthesis.

Inside the aquaria (ex situ), wormsnails retained producing their mucus nets which were almost invisible due to the lack of adherent particles. Defecation was frequent (24 times $\mathrm{h}^{-1}$ ) and ejected as pellets in batches leading to the cleanup of all facilities as well as the contamination of veils which had to be discarded. Wormsnails kept on generating slime nets for approximately 24 hours, until they stopped and could not be motivated again without additional feeding. During the final analysis, the wormsnails secreted a small bolus of mucus that accumulated on the uppermost lip of the operculum.

Bioactive metabolites, detected in situ, could also be found in extracts from nets collected ex situ (Figure 2(b)). The digital detection of the inverted (grey-scale) bioluminescence signals showed the same intensity of bioluminescence inhibition concerning the most nonpolar substances (M4 and M5) between equal concentrated extracts of in situ and ex situ sampling (Figure 3). All other metabolites disclosed stronger effects in the in situ extracts compared to the ex situ pendants. The ratio of bioluminescence inhibition between metabolite five and one is M1 > M5 in the in situ extracts including plankton and M1 < M5 in ex situ extracts excluding plankton (Figure 3). Same results were obtained for M4. Thus, M4 and M5 seemed to (exclusively) synthesize or accumulate from the wormsnail itself whereas M1 is of planktonic origin. Despite using filtered seawater, the ex situ extracts were not completely free of plankton. This was due to inserting some microfauna and flora attached to the coral blocks the wormsnails live inside. The inserted particles could have been trapped in the veils in small amounts leading to grayish spots (M1) also in the ex situ extracts. Extracts of surrounding sediments and plankton caught by a $15 \mu \mathrm{m}$ plankton net only exhibited the polar or further non polar bioactive substances eluting later on the HPLTC plate (data not shown). This is the first record of bioactivity in the whole family of Vermetidae.

\section{Discussion}

4.1. First Record of Bioactivity in the Mucus Nets of Vermetids. This study is the first report of bioactive substances in mucus 
TABLE 1: List of reef fish and their preferred feeding mode that share the same habitat like wormsnails.

\begin{tabular}{|c|c|c|}
\hline Family & Genus/species & Feeding \\
\hline Acanthuridae & Acanthurus sohal & Algae, zooplankton \\
\hline Acanthuridae & Naso elegans & Brown algae \\
\hline Acanthuridae & Naso unicornis & Brown algae \\
\hline Acanthuridae & Zebrasoma xanthurum & Algae \\
\hline Apogonidae & Apogon spp. & Fishes, crustaceans, zooplankton \\
\hline Balistidae & Rhinecanthus assasi & Benthic invertebrates \\
\hline Blenniidae & Cirripectes castaneus & Benthic algae \\
\hline Blenniidae & Ecsenius dentex & Thread algae \\
\hline Blenniidae & Ecsenius gravieri & Thread algae \\
\hline Chaetodontidae & Chaetodon auriga & Polychaetes, anemones, coral polyps and mucus, algae \\
\hline Chaetodontidae & Chaetodon austriacus & Coral polyps and mucus, cnidarian tentacles \\
\hline Chaetodontidae & Chaetodon fasciatus & Cnidarian polyps and mucus, invertebrates, algae \\
\hline Chaetodontidae & Chaetodon paucifasciatus & Coral polyps and mucus, invertebrates, algae \\
\hline Chaetodontidae & Heniochus intermedius & Zooplankton, benthic invertebrates \\
\hline Cirrhitidae & Paracirrhites forsteri & Fishes, crustaceans \\
\hline Holocentridae & Sargocentron diadema & Snails, polychaetes, crustaceans \\
\hline Labridae & Cheilinus lunulatus & Benthic invertebrates like molluscs and crustaceans \\
\hline Labridae & Gomphosus caeruleus & Small fish, benthic invertebrates \\
\hline Labridae & Halichoeres hortulanus & Benthic invertebrates \\
\hline Labridae & Labroides dimidiatus & Fish parasites, skin and mucus \\
\hline Labridae & Thalassoma lunare & Small fish, benthic invertebrates \\
\hline Labridae & Thalassoma rueppelii & Small fish, benthic invertebrates \\
\hline Mullidae & Parupeneus spp. & Fishes, benthic invertebrates \\
\hline Ostraciidae & Ostracion cyanurus & Sessile invertebrates, sponges, algae \\
\hline Ostraciidae & Tetrasomus gibbosus & Benthic, sessile invertebrates \\
\hline Pomacanthidae & Pygoplites diacanthus & Sponges, tunicates \\
\hline Pomacentridae & Abudefduf spp. & (zoo)plankton, algae \\
\hline Pomacentridae & Amblyglyphidodon spp. & Zooplankton, drifting organic material \\
\hline Pomacentridae & Chromis spp. & Plankton, algae, (omnivores) \\
\hline Pomacentridae & Chromis viridis & Plankton \\
\hline Pomacentridae & Dascyllus aruanus & Zooplankton, benthic invertebrates, algae \\
\hline Pomacentridae & Dascyllus trimaculatus & Algae, planktonic crustaceans (copepods) \\
\hline Pomacentridae & Pomacentrus trilineatus & Invertebrates, algae \\
\hline Pomacentridae & Stegastes nigricans & Algae, gastropods, sponges, copepods \\
\hline Pseudochromidae & Pseudochromis spp. & Crustaceans, worms, zooplankton \\
\hline Scaridae & Chlorurus gibbus & Benthic grazer of algae \\
\hline Scaridae & Hipposcarus harid & Thread algae \\
\hline Scaridae & Scarus spp. & Thread algae, benthic algae \\
\hline Serranidae & Cephalopholis sp. & Fishes, crustaceans \\
\hline Serranidae & Epinephelus fasciatus & Fishes, crustaceans \\
\hline Serranidae & Epinephelus tauvina & Fishes \\
\hline Serranidae & Pseudanthias spp. & (zoo)plankton \\
\hline Tetraodontidae & Arothron diadematus & Invertebrates, algae \\
\hline Tetraodontidae & Arothron hispidus & $\begin{array}{l}\text { Invertebrates (sponges, tunicates, worms, crustaceans, } \\
\text { corals, molluscs, echinoderms), algae }\end{array}$ \\
\hline
\end{tabular}




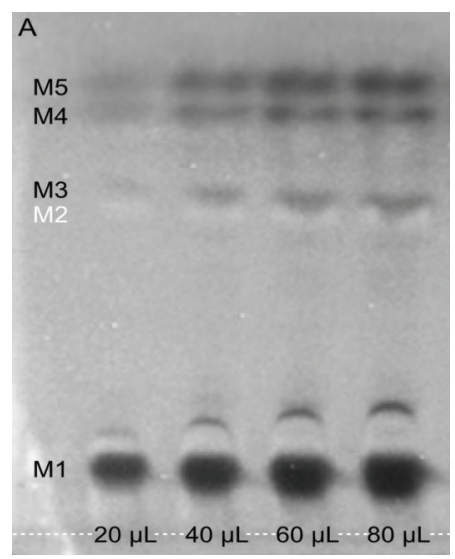

(a)

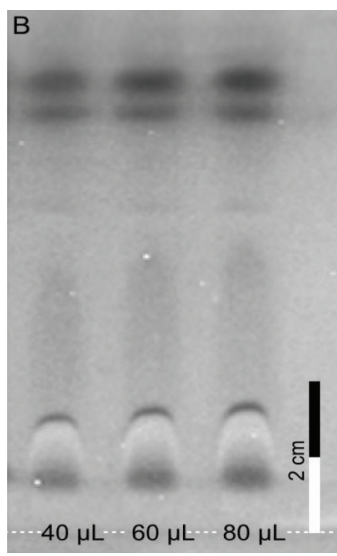

(b)

FIGURE 2: HPTLC plate image (detail) obtained from the screening for bioactive secondary metabolites in ethyl acetate extracts $\left(\sim 5\right.$ veils $\mathrm{mL}^{-1}$ solvent) of in situ (with plankton, (a)) and ex situ (without plankton, (b)) mucus nets from Dendropoma maxima. Detection was performed after the plate was immersed into a bioluminescent Vibrio fischeri suspension. M1-M5: bioactive metabolites with decreasing polarity; dotted line displays zone of application. Concentrations on plate: 20-80 $\mu \mathrm{L} / \mathrm{band}$. Dark spots denote luminescence inhibition (M1, M3-M5); white spots (M2) denote luminescence enhancement. $N=5$.

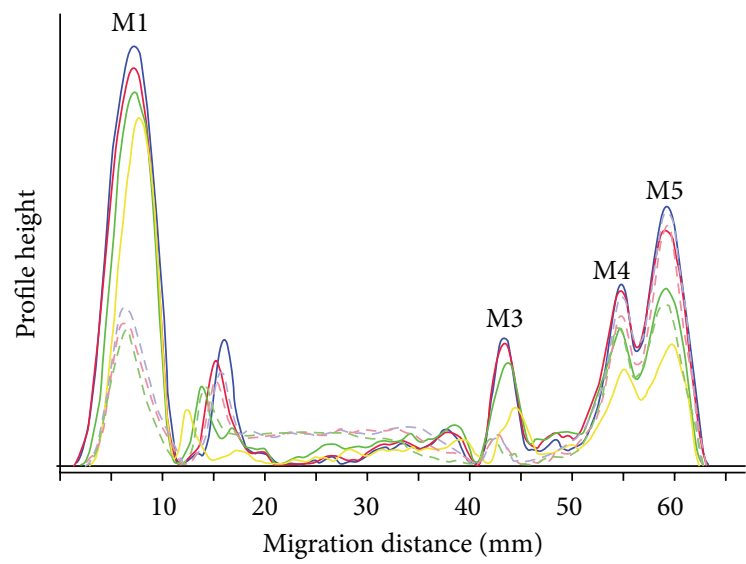

Figure 3: Digital detection of the inverted (grey-scale) bioluminescence signal of respective tracks. Each extract was made of $\sim 5$ nets educed in $1 \mathrm{~mL}$ ethyl acetate. M1-M5: bioactive metabolites with decreasing polarity. Lines bright coloured $=$ nets with plankton sampled in situ, lines light coloured = nets without plankton sampled ex situ. Concentrations on plate: blue: $80 \mu \mathrm{L} / \mathrm{band}$, red: $60 \mu \mathrm{L} / \mathrm{band}$, green: $40 \mu \mathrm{L} / \mathrm{band}$, and yellow: $20 \mu \mathrm{L} / \mathrm{b}$ and. Due to equal intensities of M4 and M5 and the inverse ratio of M1/M4 and M1/M5 in both extracts (in situ: M4 and M5 < M1, ex situ: M4 and M5 > M1) of same concentration, M4 and M5 seem to exclusively be synthesised or accumulated by the wormsnail itself whereas M1 is of planktonic origin. $N=3$.

nets of the family Vermetidae. Although it was already presumed in 1973 by Coles and Strathmann [19] and despite the already known occurrence of toxic compounds in many mucus releasing invertebrates, no study has been completed on the detection of bioactive secondary metabolites in vermetids. The compounds could be either of gastropod's origin synthesized by the wormsnail itself, accumulated via passive suspension feeding, or built up starting from diet-derived precursors. Here we suggest that M4 and M5 are exclusively produced by the vermetid itself due to equal bioluminescence inhibition of these metabolites and the inverse ratio of M1 and M5 (or M1 and M4) between in situ and ex situ extracts (Figure 3). Traces of M1 to M3 along the HPTLC plate of clean extracts are presumably due to small amounts of plankton transferred to the ex situ tanks, for example, microfauna and flora attached to the coral block, that got caught in the mucus veils. In case the bioactive metabolites would not be accumulated by the wormsnail but by the plankton, the ratio of substance amounts-and therefore the intensity of bioluminescence inhibition-between M1 and M4 as well as M5 and all the other metabolites should be constantly equal. This requires the equality of the qualitative and quantitative composition of the remaining planktonic organisms in the ex situ tank and the in situ habitat. The secretion of mucus agglomerates from animals that kept in aquaria for more than 24 hours was also observed by Yonge [42]. These attributes led to the conclusion that D. maxima uses the bolus to consolidate filtered particles prior to ingestion. Since filter feeding is possible but negligible in D. maxima and it is fully adapted to mucus-trap feeding continuously nourishing on slime nets, the bolus seems to be an artifact of ex situ conditions.

4.2. Trophic Significance and Biotoxicity/Ichthyotoxicity of Mucoidal Material. The significance of mucoidal material of either fish or invertebrate origin as food source for tropical marine fishes is well known (e.g., [43-45]). External mucus slime provides the predator with a rich, continuously renewed resource of energy and amino acids that may comprise more than $95 \%$ of their diet $[46,47]$. Lipids, particularly wax esters, and mucins containing glucose, galactose, glucosamine, galactosamine, and arabinose were found to be a major, consistent component of coral mucus [43, 47]. The molluscan mucus is phylogenetically and functionally 
different from coelenterate mucins but seems quite similar to them chemically [47]. Predators feeding on mucus are Labroides spp. cleaning wrasses (Labridae) or juvenile angelfish (Pomacanthidae) but also noncleaning fish like cichlids [44, 48]. Further families including mucoid reef fish are the Chaetodontidae (predominant feeding mode), Tetraodontidae, Balistidae, Monacanthidae, Pomacentridae and Scaridae [45]. Corallivores are well known to feed compulsively or facultatively on the nutritious slime of live coral polyps. Several corals (e.g., Acropora spp., Porites spp.) release large aggregates of denatured mucus that becomes suspended and floats in the water column. These flocks, additionally containing algae, occasional protozoa, organic debris, filamentous algae, and crustacean molts, as well as inorganic particles, are highly energy enriched and may be an important food source $[19,43,47,49,50]$.

However, our study gives no information whether bioactive substances are responsible for coral tissue degeneration or have ichthyotoxic properties concerning habitat sharing reef fish. The antibiotic effect may also be used to reduce the degradation of plankton by bacteria while it is trapped within the net. Bioactive metabolites could be the explanation for mucoid and plankton feeding reef fish not being interested in the veils as noted and presumed before [19]. Our findings that several species of Chromis sp. ignore the mucus nets contradict with the studies completed by Johannes [49], who showed that these fish have a preference for mucus sheets in general. It is also possible that reef fish ignore the webs because of their dimension, as seen with macroscopic mucus aggregates from corals [19]. Further analyses are needed to study the correlation between the separated metabolites and their effect.

4.3. Effect of Vermetids on Coral Morphology and Survival. The deleterious influence of mucus nets on coral morphology leading to, for example, the flattened shape, even surface and air bubble trapping was also previously reported (e.g., [1, 13]). Flattened corals cannot block the horizontal component of the local currents and may enable the gastropods' webs to spread over the coral head. Thus, the mucus net may be secreted over a larger area [1]. A comparable strong coral degradation marked by the exposure of dead tissue overgrown by algae (Figure 1(c)) is also published in [13]. They revealed a negative correlation between the local density of vermetids and the percent cover of live coral. Further timeseries recordings are planned to analyze whether the reported different stages of hostcoral interaction reflect a real gradient across time. In contrast to our studies, Zvuloni and coworkers [1] also observed branching corals, for example, the hydrozoan Millepora sp., dramatically affected by the gastropods mucus nets. This may end in the loss of the coral's typical terminal polyps [1]. Until now, there is no explanation for the observed deformations and degenerations of corals. The physiological effects and the exact mechanisms underlying vermetid-coral interactions remain unknown. The following hypotheses were presumed: (1) occluding mucus nets reduce the water flow around the corals and prevent them from feeding on plankton inducing competition pressure (Colgan in [9]), (2) mucus nets have an abrasive effect on coral polyps (own suggestion), (3) D. maxima consumes the coral's (secondary) metabolites and/or their mucus (suggested by Fenner [51]), and (4) mucus nets contain chemicals that influence coral growth (suggested by Zvuloni and coworkers [1], own suggestion in combination with (2)).

4.4. Conclusion/Outlook. This is the first record of bioactive properties in mucus producing organisms belonging to the Vermetidae. Ex situ feeding experiments with isolated substances are in progress to study further potential bioactive properties (e.g., ichthyotoxicity) besides the antimicrobial effect. Additionally, analyses are ongoing to elucidate the structural formula of the acting compounds by HPTLC/HRMS. We suggest that other mucus net producing taxa (e.g., polychaetes) also contain bioactive substances what open a new field in the search for marine natural products with possible application in human medicine.

\section{Conflict of Interests}

There is no conflict of interests in the submitted paper.

\section{Acknowledgments}

The authors thank the DiveIn, Dahab, all the staff, especially Andreas Tischer, and Hans Lange for their support and providing equipment; the Dahab Marine Research Center (DMRC) and all interns "milking" the wormsnails, Stefan Rauchut, and Tim Cross; furthermore, special thanks to Nils Anthes, University of Tübingen for sparking the interest in wormsnails and providing the literature. The authors are thankful to Merck, Darmstadt, Germany, and CAMAG, Berlin, Germany, for support regarding plate material and instrumentation, respectively.

\section{References}

[1] A. Zvuloni, R. Armoza-Zvuloni, and Y. Loya, "Structural deformation of branching corals associated with the vermetid gastropod Dendropoma maxima," Marine Ecology Progress Series, vol. 363, pp. 103-108, 2008.

[2] R. N. Hughes and A. H. Lewis, "On the spatial distribution, feeding, and reproduction of the vermetid gastropod Dendropoma maximum," Journal of Zoology, vol. 172, pp. 531-547, 1974.

[3] M. G. Hadfield, E. A. Kay, M. U. Gillette, and M. C. Lloyd, "The vermetidae (Mollusca: Gastropoda) of the Hawaiian Islands," Marine Biology, vol. 12, no. 1, pp. 81-98, 1972.

[4] M. Zuschin and W. E. Piller, "Molluscan hard-substrate associations in the northern Red Sea," Marine Ecology, vol. 18, no. 4, pp. 361-378, 1997.

[5] N. E. Phillips and J. S. Shima, "Reproduction of the vermetid gastropod dendropoma maximum (Sowerby, 1825) in moorea, french polynesia," Journal of Molluscan Studies, vol. 76, no. 2, pp. 133-137, 2010.

[6] G. Ribak, J. Heller, and A. Genin, "Mucus-net feeding on organic particles by the vermetid gastropod Dendropoma maximum in and below the surf zone," Marine Ecology Progress Series, vol. 293, pp. 77-87, 2005. 
[7] M. Zuschin and M. Stachowitsch, "The distribution of molluscan assemblages and their postmortem fate on coral reefs in the gulf of aqaba (northern red sea)," Marine Biology, vol. 151, no. 6, pp. 2217-2230, 2007.

[8] I. Kappner, S. M. Al-Moghrabi, and C. Richter, "Mucus-net feeding by the vermetid gastropod Dendropoma maxima in coral reefs," Marine Ecology Progress Series, vol. 204, pp. 309313, 2000.

[9] T. L. Smalley, "Possible effects of intraspecific competition on the population structure of a solitary vermetid mollusc," Marine Ecology Progress Series, vol. 14, pp. 139-144, 1984.

[10] R. Hughes, "Feeding behaviour of the sessile gastropod Tripsycha tulipa (Vermetidae)," Journal of Molluscan Studies, vol. 51, pp. 326-330, 1985.

[11] A. Gagern, T. Schürg, N. K. Michiels, G. Schulte, D. Sprenger, and N. Anthes, "Behavioural response to interference competition in a sessile suspension feeder," Marine Ecology Progress Series, vol. 353, pp. 131-135, 2008.

[12] C. R. Boettger, "Studien zur Physiologie der Nahrungsaufnahme festgewachsener Schnecken. Die Ernährung der Wurmschnecke Vermetus," Biologisches Zentralblatt, pp. 581-598, 1930.

[13] J. S. Shima, C. W. Osenberg, and A. C. Stier, "The vermetid gastropod Dendropoma maximum reduces coral growth and survival," Biology Letters, vol. 6, no. 6, pp. 815-818, 2010.

[14] J. E. Morton, "Form and function in the evolution of the Vermetidae," Bulletin of the British Museum (Natural History). Zoology, vol. 2, pp. 585-630, 1965.

[15] N. E. Chadwick and K. M. Morrow, "Competition among sessile organisms on coral reefs," in Coral Reefs: An Ecosystem in Transition, Z. Dubinsky and N. Stambler, Eds., pp. 347-372, US Government, 2011

[16] A. C. Stier, C. S. McKeon, C. W. Osenberg, and J. S. Shima, "Guard crabs alleviate deleterious effects of vermetid snails on a branching coral," Coral Reefs, vol. 29, no. 4, pp. 1019-1022, 2010.

[17] R. H. Lowe-McConnell, Fish Communities in Tropical Freshwaters, Longman Press, London, UK, 1975.

[18] P. A. Larkin, "Interspecific competition and population control in freshwater fish," Journal of the Fisheries Research Board of Canada, vol. 13, pp. 327-342, 1956.

[19] S. L. Coles and R. Strathmann, "Observations on coral mucus "flocs" and their potential trophic significance," Limnology and Oceanography, vol. 18, pp. 673-678, 1973.

[20] M. L. Harmelin-Vivien and Y. Bouchon-Navaro, "Feeding diets and significance of coral feeding among Chaetodontid fishes in Moorea (French Polynesia)," Coral Reefs, vol. 2, no. 2, pp. 119127, 1983.

[21] V. DiMarzo, A. Marin, R. R. Vardaro, L. DePetrocellis, G. Villani, and G. Cimino, "Histological and biochemical bases of defense mechanisms in four species of Polybranchioidea ascoglossan molluscs," Marine Biology, vol. 117, no. 3, pp. 367380, 1993.

[22] G. Cimino, S. De Rosa, S. De Stefano, and G. Sodano, "The chemical defense of four Mediterranean nudibranchs," Comparative Biochemistry and Physiology Part B, vol. 73, no. 3, pp. 471474, 1982.

[23] C. D. Derby, "Escape by inking and secreting: marine molluscs avoid predators through a rich array of chemicals and mechanisms," Biological Bulletin, vol. 213, no. 3, pp. 274-289, 2007.

[24] J. W. Blunt, B. R. Copp, M. H. G. Munro, P. T. Northcote, and M. R. Prinsep, "Marine natural products," Natural Product Reports, vol. 28 , no. 2, pp. 196-268, 2011.
[25] M. S. Davies and S. J. Hawkins, "Mucus from marine molluscs," Advances in Marine Biology, no. 34, pp. 1-71, 1998.

[26] T. E. Thompson, "Defensive adaptations on opisthobranchs," Journal of the Marine Biological Association of the United Kingdom, vol. 39, pp. 123-134, 1960.

[27] J. R. Pawlik, "Marine invertebrate chemical defenses," Chemical Reviews, vol. 93, no. 5, pp. 1911-1922, 1993.

[28] L. Gunthorpe and A. M. Cameron, "Bioactive properties of extracts from Australian dorid nudibranchs," Marine Biology, vol. 94, no. 1, pp. 39-43, 1987.

[29] G. Cimino, A. Fontana, and M. Gavagnin, "Marine opisthobranch molluscs: chemistry and ecology in sacoglossans and dorids," Current Organic Chemistry, vol. 3, no. 4, pp. 327-372, 1999.

[30] C. Avila, "Natural products of opisthobranch molluscs: a biological review," Oceanography and Marine Biology: An Annual Review, vol. 33, pp. 487-559, 1995.

[31] G. Cimino, A. Crispino, V. Di Marzo, M. Gavagnin, and J. D. Ros, "Oxytoxins, bioactive molecules produced by the marine opisthobranch mollusc Oxynoe olivacea from a diet-derived precursor," Experientia, vol. 46, no. 7, pp. 767-770, 1990.

[32] G. J. Bakus, N. M. Targett, and B. Schulte, "Chemical ecology of marine organisms: an overview," Journal of Chemical Ecology, vol. 12, no. 5, pp. 951-987, 1986.

[33] D. Bhakuni and D. Rawat, Bioactive Marine Natural Products, Anamaya, New Delhi, India, 2005.

[34] N. Fusetani, Drugs from the Sea, Karger, Basel, Switzerland, 2000.

[35] P. Proksch, R. Ebel, R. A. Edrada, V. Wray, and K. Steube, "Bioactive natural products from marine invertebrates and associated fungi," in Sponges (Porifera), W. E. G. Müller, Ed., pp. 117-142, Springer, Berlin, Germany, 2003.

[36] D. J. Newman and G. M. Cragg, "Marine natural products and related compounds in clinical and advanced preclinical trials," Journal of Natural Products, vol. 67, no. 8, pp. 1216-1238, 2004.

[37] P. Proksch and W. E. G. Muller, Frontiers in Marine Biotechnology, Horizon Bioscience, Wymondham, UK, 2006.

[38] A. M. S. Mayer, K. B. Glaser, C. Cuevas et al., "The odyssey of marine pharmaceuticals: a current pipeline perspective," Trends in Pharmacological Sciences, vol. 31, no. 6, pp. 255-265, 2010.

[39] A. Klöppel, W. Grasse, F. Brümmer, and G. E. Morlock, "HPTLC coupled with bioluminescence and mass spectrometry for bioactivity-based analysis of secondary metabolites in marine sponges," Journal of Planar Chromatography, vol. 21, no. 6, pp. 431-436, 2008.

[40] E. Lieske and R. Myers, Coral Reef Guide Red Sea, FranckhKosmos Verlags, GmbH \& Co. KG, Stuttgart, Germany, 2004.

[41] R. Froese and D. Pauly, "FishBase. World Wide Web electronic publication. Version (04/2013)," 2013, http://www.fishbase.org/search.php.

[42] C. M. Yonge, Notes on Feeding and Digestion in Pterocera and Vermetus, with a Discussion on the Occurence of the Crystalline Style in the Gastropoda, vol. 1 of Great Barrier Reef Expedition 1928-1929, Scientific Report, 1932.

[43] A. A. Benson and L. Muscatine, "Wax in coral mucus: energy transfer from corals to reef fishes," Limnology and Oceanography, vol. 19, pp. 810-814, 1974.

[44] D. L. Gorlick, "Ingestion of host fish surface mucus by the Hawaiian cleaning wrasse, Labroides phthirophagus (Labridae), and its effect on host species preference," Copeia, vol. 4, pp. 863$868,1980$. 
[45] A. J. Cole, M. S. Pratchett, and G. P. Jones, "Diversity and functional importance of coral-feeding fishes on tropical coral reefs," Fish and Fisheries, vol. 9, no. 3, pp. 286-307, 2008.

[46] K. O. Winemiller and H. Y. Yan, "Obligate mucus-feeding in a South American trichomycterid catfish (Pisces: Ostariophysi)," Copeia, vol. 2, pp. 511-514, 1989.

[47] H. W. Ducklow and R. Mitchell, "Composition of mucus released by coral reef coelenterates," Limnology and Oceanography, vol. 24, pp. 706-714, 1979.

[48] A. S. Grutter and R. Bshary, "Cleaner fish, Labroides dimidiatus, diet preferences for different types of mucus and parasitic gnathiid isopods," Animal Behaviour, vol. 68, no. 3, pp. 583-588, 2004.

[49] R. E. Johannes, "Ecology of organic aggregates in the vicinity of a coral reef," Limnology and Oceanography, vol. 12, pp. 189-195, 1967.

[50] S. Richman, Y. Loya, and L. B. Slobodkin, "The rate of mucus production by corals and its assimilation by the coral reef copepod Acartia negligens," Limnology and Oceanography, vol. 20, pp. 918-923, 1975.

[51] D. Fenner, "Is a mollusc that scupltures coral a parasite?" in Proceedings of the 82nd Australian Coral Reef Society Conference, Mission Beach, Australia, 2006. 

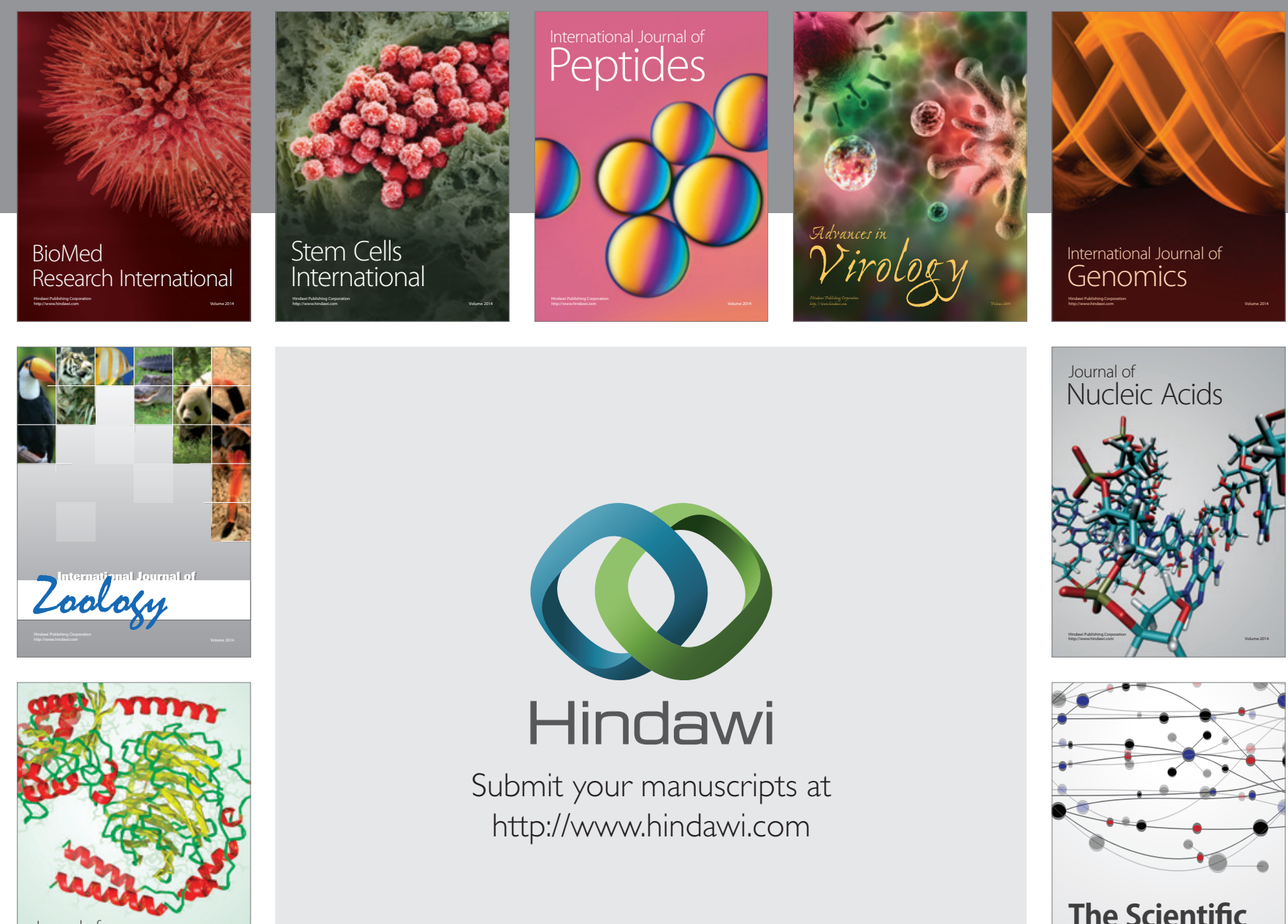

Submit your manuscripts at

http://www.hindawi.com

Journal of
Signal Transduction
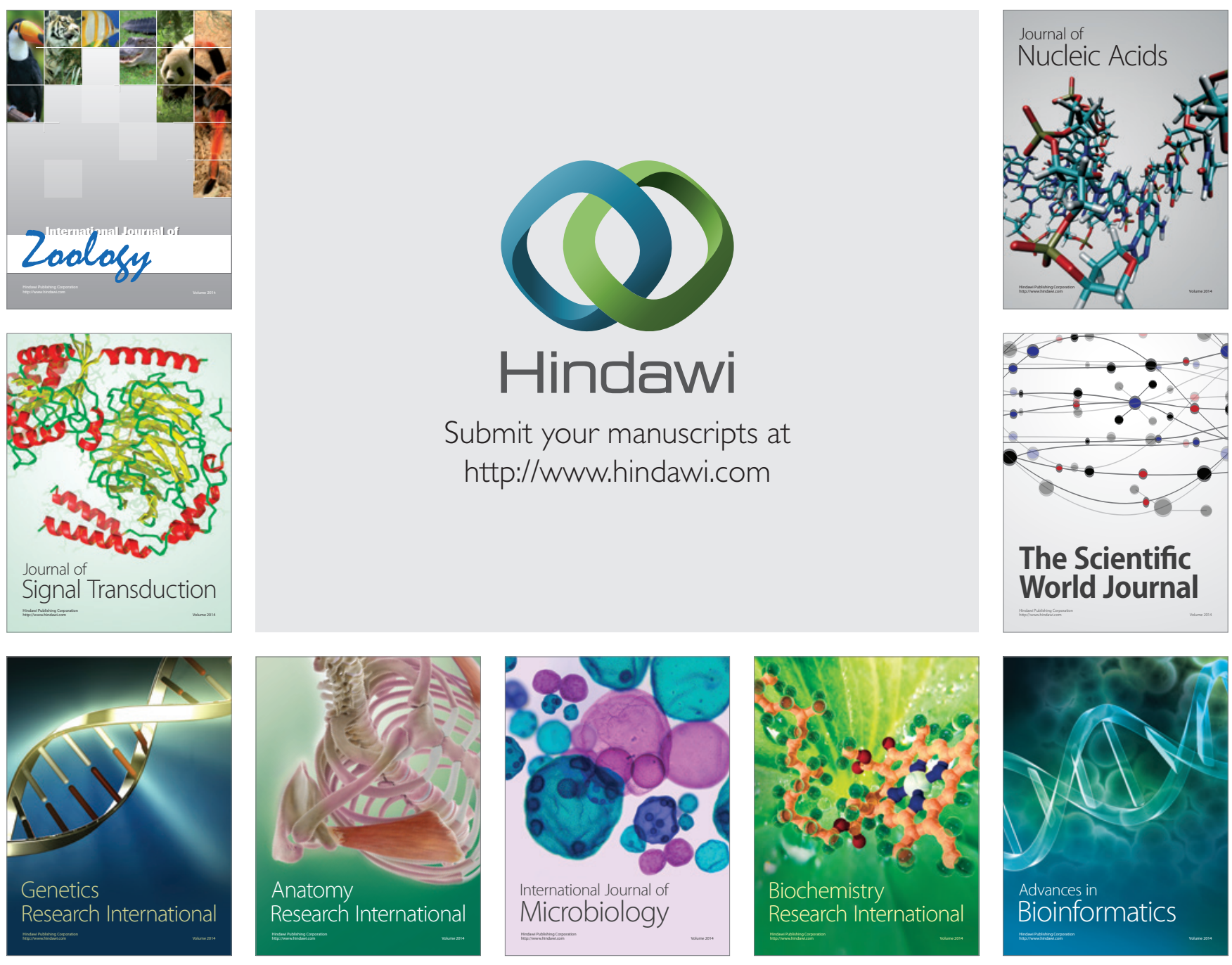

The Scientific World Journal
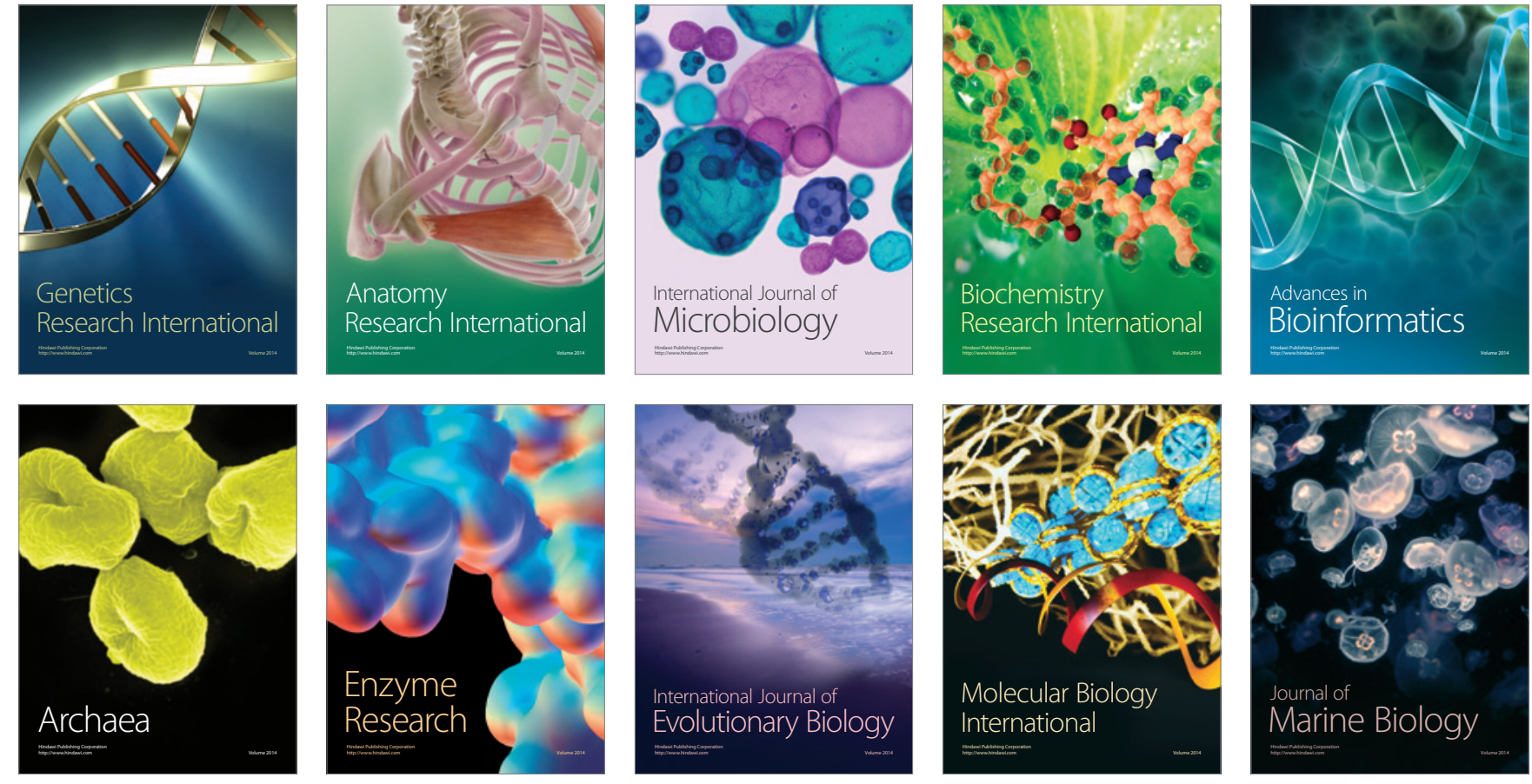